\title{
Research on Paths to Cultivate Occupational Quality of Higher Vocational College Students under the Guidance of Spirit of the Craftsman
}

\author{
Li Pan \\ Ningbo City College of Vocational Technology \\ Ningbo, China
}

\begin{abstract}
Spirit of the craftsman plays a distinctly important role in the implementation of Made in China 2025, having great significance on the survival of enterprises, the development of higher vocational colleges and career planning of higher vocational college students. In cultivation of students' occupational qualities, higher vocational colleges must attach importance to the guidance of spirit of the craftsman and strengthen students' occupational qualities through professional course, practical training, ideological and political course, campus culture and off-campus resources, and carry forward spirit of the craftsman.
\end{abstract}

Keywords-spirit of the craftsman; occupational quality; cultivate; higher vocational colleges

\section{INTRODUCTION}

On Mar. 5, 2016, Premier of the State Council, Li Keqiang proposes in the Report on the Work of the Government on the Fourth Session of the 12th National People's Congress that "We will encourage enterprises to use flexible and custom-tailored production processes and foster a craftsmanship spirit of striving for the best, so that more types of products, products of higher quality, and brand products will be made". In March 29, Premier Li Keqiang emphasizes on the second award-giving meeting of China quality award that "carry forward spirit of the craftsman, guarantee quality and make more famous satisfactory brands, and let the pursuit of excellence and high quality become the value guidance and spirit of the time of the whole society and nation." In April 26 of this year, President Xi Jinping emphasizes on the forum with presence of intellectuals, model workers and youth representatives that "carry forward spirit of the craftsman, elaborately produce each part to produce high quality products". In April 28, Li Jianguo, chairman of ACFTU (All China Federation of Trade Unions) proposes on celebration of May Day and the national May 1 labor award commendation conference that "we must cultivate more craftsman of great country and vigorously carry forward spirit of the craftsman in the new period". The year of 2016 is the beginning year of the 13th Five-year Plan. It clearly proposes in the Outline of the 13th Five-year Plan of our country that "we should create social atmosphere advocating profession and carry forward spirit of the craftsman in the new period".
Leaders at all levels in all circles repeatedly propose the requirements of cultivating and carrying forward "Spirit of the Craftsman". It attracts the attention of all sectors of society. "Spirit of the Craftsman" has importance significance on promotion of "mass entrepreneurship and mass innovation", implementation of "Made in China 2005" and realization of "the Chinese Dream" of the great rejuvenation of the Chinese nation.

\section{INTRODUCTION TO "SPIRIT OF THE CRAFTSMAN"}

What is "spirit of the craftsman"? Different people hold different opinions. Wang Liyuan defines it in Research on Necessity and Feasibility of Cultivating Students' Spirit of the Craftsman in Higher Education, "spirit of the craftsman is an occupational attitude and spiritual idea, the professional value orientation and behavioral expression of employees that closely relate to their outlook on life and values". Spirit of craftsman requires employees to strive for the best, insist on pursuing quality goods; spend time and energy to make perfect details; hold serious, cautious, meticulous and comprehensive attitudes toward work; show patience, concentration and persistence; keep high standard and strict requirements for quality and pay attention to the quality of products and service; be professional and devote to work, be serious and responsible to create products of the best quality, make unremitting efforts and continuous improvement.

Great powers of manufacture like Germany and Japan realize the value of spirit of the craftsman, so that they shape and cultivate students' spirit of the craftsman in vocational education. It is one of the secrets that Germany and Japan take the leading position in international competition of manufacturing industry especially high-end manufacturing for a long time.

High quality technical personnel must have high occupational qualities, which form and develop through educational training, professional practice and selfcultivation by employees based on physical and psychological conditions. It refers to the basic steady quality that plays a decisive role in occupational activities, mainly

\footnotetext{
${ }^{1}$ Wang Liyuan: Research on Necessity and Feasibility of Cultivating Students' Spirit of the Craftsman in Higher Education, Vocational and Technical Education Forum, the $22^{\text {nd }}$ Issue of 2014, P66
} 
including professional ethics, skills, attitudes, habits and emotions to serve the development of employees' professional career. Formative education of higher vocation college students' occupational qualities uses daily management, guidance, influence, training and evaluation to realize cyclic action and supplement of internal force of "cultivation" of students and external force of "education" of schools and enterprises to let students develop basic quality of "professional people". Formative education of occupational qualities trains students' nonintellectual factors related to vocational development. According to the connotation of occupational qualities, it is not difficult to find occupational qualities and the spirit of the craftsman run parallel. Spirit of the craftsman is an attitude of employees toward occupation and an important part of occupational qualities. Occupational qualities are the foundation to form spirit of the craftsman. Spirit of the craftsman is the highest embodiment of occupational qualities.

Higher vocational colleges shoulder the mission of cultivating high quality technical personnel in front line of production, management, construction and service. As the main unit to provide manufacturing talents, higher vocational colleges should improve students' professional quality and train their "spirit of the craftsman". Therefore, higher vocational colleges should carry out researches on training excellent talents with "spirit of the craftsman" and train more "craftsman of great country".

\section{SIGNIFICANCE ON CARRYING FORWARD “SPIRIT OF THE CRAFTSMAN" BY HighER VOCATIONAL COLLEGES}

The significance on carrying forward "spirit of the craftsman" by higher vocational colleges embodies in four aspects, including country, enterprises, higher vocational colleges and self-development of higher vocational college students.

\section{A. First, Carrying Forward Spirit of the Craftsman Is the Requirement of Upgrade and Development of Economic Transformation}

The cultivation and inheritance of spirit of the craftsman is important factor of the success of international great powers of manufacture. Applying spirit of the craftsman incisively and vividly can make industrial products of our country have competitive advantages, become irreplaceable in some fields and remain invincible in the complicated international market in the medium and long term, so that our country will become true great power of manufacture. Carrying forward spirit of the craftsman is the practical need to realize upgrade of economic transformation and develop manufacturing industry in China. Except for continuously pursuing scientific and technological progress, our country should train and form a team of skilled talents with strong technology and high quality to realize "transformation and upgrading".

\section{B. Second, Spirit of the Craftsman Is An Important Guarantee for Survival and Development of Enterprises}

The core of spirit of the craftsman-pursuit of best products is one of the secrets that enterprises remain invincible, as well as an edge tool of brands to take the leading position. In order to remain invincible in competition, enterprises must manufacture high quality products and have technology of independent research and development and enterprise culture of striving for the best and people orientation.

\section{Third, Spirit of the Craftsman Is the Requirement for Survival and Development of Higher Vocational Colleges}

Higher vocational colleges are market-oriented, aim at students' employment so they must value the demands of enterprises for talents. Except for necessary vocational skills, enterprises hope graduates have job responsibility. If higher vocational colleges train students' professional spirit, especially spirit of the craftsman, it will strengthen students' employment competitiveness and make graduates popular with enterprises and have good social reputation. It promotes the survival and development as well as sustainable development of higher vocational colleges.

\section{Fourth, Spirit of the Craftsman Is the Practical Need of Employment and Development of Professional Career of Students}

In cultivation of students' occupational qualities, if higher vocational colleges can train their spirit of the craftsman, it will greatly improve the additional value of human capital and promote employment of higher vocational college students and the development of professional career. Like high professional knowledge and skills, strong professional spirit especially the spirit of the craftsman is important condition for higher vocational college students to enter and exist in the society.

\section{Paths to Cultivate Higher Vocational COLLEGE STUDENTS' OCCUPATIONAL QUALITIES UNDER THE GUIDANCE OF SPIRIT OF THE CRAFTSMAN}

Domestic higher vocational colleges value the training of students' vocational skills but often neglect the training of their occupational qualities. In specialty construction, course construction, base construction, construction of teaching staff and talent training, some schools offer more popular specialties related to hottest occupations in society but attach inadequate importance to regular specialties that require elaboration. Courses of many specialties have shallow teaching contents and simple skills and lack the cultivation of occupational qualities. Although some schools do better in skill training, they do not value the training of "spirit of the craftsman" and sustainable development of students" professional career, and quality requirements of students' professional and career growth, but pay excessive attention to momentary demands of society and enterprises. Moreover, higher vocational college students have passive learning habits and lack the spirit of studying hard, so some students 
lack confidence and perseverance when facing problems. It brings difficulties for higher vocational colleges in cultivation of "spirit of the craftsman" and vocational qualities.

Furthermore, because the in-school time of higher vocational college students is four years most, it is difficult to train students into skillful craftsman in all walks of life. Under the guidance of "spirit of the craftsman", combine the cultivation of occupational qualities with spirit of the craftsman to influence students imperceptibly and lay quality foundation for students to become skillful craftsman after graduation.

Under the leadership of spirit of the craftsman, higher vocational colleges integrate and reasonably arrange educational resources to effectively cultivate students' occupational qualities through many ways.

\section{A. Integrate Contents Related to Cultivation of Occupational Qualities in Learning Professional Courses to Let Students Set Up the Spirit of the Craftsman}

In setting of talent objectives and course objectives, selection of teaching contents and formulation of evaluation methods, teachers should consider the factors related to cultivation of occupational qualities under the guidance of spirit of the craftsman. When students learn professional knowledge, teachers consciously teach spirit of the craftsman to students to let them roundly grasp knowledge, finish assignments seriously and study hard. Meanwhile, teachers train students to grasp methods and skills of investigative study, develop the habit of learning while research, concluding while improving, and improve their ability in find, analyze and solve problems. All in all, in professional teaching, teachers should connect the latest occupational standard, industrial standard and post criterion and integrate knowledge, skills and professional quality required by professional posts in teaching.

\section{B. Integrate Requirements of Occupational Qualities in Practical Training and Develop Concept of Students in Pursuing Spirit of the Craftsman}

Practical teaching is the most unique part in the system of higher vocational education. It means students apply all knowledge learnt by students including knowledge in ideological and political theory course and professional courses to production and operation and complete a work flow independently. Students simulate real scenes in enterprises and occupational activities in the practical training. It integrates requirements of professional knowledge, skills and professional quality to practical training and train knowledge, skills and occupational qualities of students.

In skill training, teachers have high standards and strict requirements for skills of students and require students to train repeatedly to have exquisite craftsmanship. Teachers highlight students' dominant position, arouse their enthusiasm and let them operate and apply actually and solve problems encountered in operation. Students are cultivated into talents with innovation consciousness through using knowledge to serve the development of professional career. Teachers guide students to be brave in face of difficulties and strive for the best in professional skill training and develop occupational qualities as well as carry forward "spirit of the craftsman".

\section{Integrate Cultivation of Occupational Qualities in Ideological and Political Course and Train The Spirit of Craftsman of Students to Become "Craftsman" and \\ "Integrated Man"}

Students' service ability can improve continuously on the job after graduation, but schools should teach them how to behave and train their job responsibility before the world outlook, outlook on life and values of students are established.

In ideological and political course, higher vocational colleges can choose, change and recombine educational contents, organically digest contents and guide students to understand what kind of technological development can seek benefits for human society and the technological innovation that conforms to the law of social development is correct for their professional and personal development. Combine the world outlook, outlook on life and values in Marxism with moral motivation and behavior of craftsman and launch technological development that centers on ethical goals of becoming "integrated man", "conscientious" and "kind", to improve their pursuit of craftsman for occupation.

In ideological and political education, students should be cultivated to be indifferent to fame and wealth and pursue skills attentively and tenaciously. Concentrated and persistent belief is the basis of successful career and the basic factor of training "spirit of the craftsman". It is more possible for people with concentrated and persistent belief to succeed and get fame and wealth. It is very difficult to make great achievements if people weigh gains and losses excessively, or lack lofty pursuit and refuse to sacrifice time, energy and economy. Courage and wisdom is required to carry forward "spirit of craftsman" in ideological and political education. We should not seek quick success and instant benefits and consider ourselves always right but combine "operation" with "thinking", "hand" with "mind" and "behavior" with "knowledge".

\section{In Construction Of Campus Culture, Combine With Cultivation Of Occupational Qualities Of Students And Attach Importance To Education Of Becoming "Integrated Man"}

The nature of education is to make people become "integrated man". Vocational education has particularity of its own and generality of the nature of education. It should be education of becoming "integrated man", in order to train social citizens with responsibility and integrated development and have enthusiasm in participating in social life, promote the harmonious development of life, morality, emotion, reason and technology of people. Higher vocational colleges are not to train robots but integrated man. They can create an atmosphere of spirit of the craftsman for students 
through campus culture and activities like speech, contest and exhibition. It enriches students' spare-time cultural life and expands their scope of knowledge, training their practical ability and promoting the cultivation of their occupational qualities.

\section{E. In Application of Off-Campus Resources, Cultivate Occupational Qualities and Attach Importance to Spirit of the Craftsman}

Higher vocational colleges can help students to realize the value of spirit of the craftsman through interviewing and visiting enterprises and inviting skilled experts to give lectures. Students understand the requirements of enterprises for the professional quality of employees and the importance of spirit of the craftsman in employment and vocational development. The analysis on spirit of the craftsman by skilled experts outside school guides students to form the professional spirit. Besides, schools should exert the example function of excellent graduates. Because their personal experience is more convincing and appealing, it has demonstration effect on cultivating spirit of the craftsman of students.

At present, many higher vocational colleges cooperate with foreign colleges in projects. Schools can encourage and subsidize students to carry out short-term exchange abroad, feel the efforts of foreign schools and enterprises in cultivation of occupational qualities and spirit of the craftsman. It may make students rethink their future and the development of career planning. At the meantime, higher vocational colleges should encourage and subsidize teachers to work, study and research and improve professional skills. It is of great advantage for cultivation of occupational qualities of higher vocational college students under the guidance of spirit of the craftsman.

\section{CONCLUSION}

To sum up, it is impossible for vocational education in higher vocational colleges to train students without practical experience into craftsman of great country, but it can effectively support students to become craftsman of great country in the future.

\section{REFERENCES}

[1] Sun Xiaoling. Discussion on Connotation of Higher Vocational Professional Spirit Based on Occupational Qualities [J], Vocational and Technical Education Forum, 2012(2)

[2] Wang Liyuan. Research on Necessity and Feasibility of Cultivating Students' Spirit of the Craftsman in Higher Vocational Education [J], Vocational and Technical Education Forum, 2014(22) 